\author{
JOURNAL OF MARINE RESEARCH AND TECHNOLOGY \\ journal homepage: https://ojs.unud.ac.id/index.php/JMRT \\ ISSN: $2621-0096$ (electronic); 2621-0088 (print)
}

\title{
Pertumbuhan Transplan Karang Lunak Sinularia polydactyla dan S. asterolobata Berdasarkan Metode Tebar Dasar dan Penempelan Substrat Pada Lokasi yang Berbeda
}

\author{
I Dewa Anom Agung Dwi Putra Jayantika ${ }^{a}$, IGB Sila Dharmaa ${ }^{a}$,Widiastutia*
}

${ }^{a}$ Program Studi Ilmu Kelautan, Fakultas Kelautan dan Perikanan, Universitas Udayana ,Bali, Indonesia

*Corresponding author, email: widiastutikarim@unud.ac.id

\section{ARTICLE INFO}

\section{Article history:}

Received: July $23^{\text {th }} 2020$

Received in revised form: September $4^{\text {th }} 2020$

Accepted: October $12^{\text {th }} 2020$

Available online: February $28^{\text {th }} 2021$

Keywords:

Soft Coral

Transplantation

Growth Rate

Survival Rate

Spreading method

Substrate-attached method

\section{ABSTRACT}

Soft coral transplantations are widely used for rehabilitation of coral reef ecosystems and commercial needs with common method are substrated-attached and placed on the metal table frame. These methods are considered as costly. This study aimed to examine the difference in the average growth of transplanted soft corals Sinularia polydactyla and S. asterolobata, spreading on the seabed and substrate-attached methods at different location. Transplantation was conducted inside and outside Pegametan Bay, Buleleng. Soft coral fragments were spread on the seabed and attached with cement. The increased sizes and survival rates of the transplanted soft corals were observed every two weeks. The differences in the average growth rates among soft coral species, transplantation methods and locations were analyzed by threefactor ANOVA and survival rates were analyzed by using the Log-Rank test. The results showed no significant difference in the average growth rates between $S$. polydactyla and $S$. asterolobata $(\mathrm{P}=0,104)$ and transplantation methods $(\mathrm{P}=0,141)$. The average growth rate of transplanted soft corals outside was significantly higher $(\mathrm{P}=0,025)$ than those inside the bay. This study indicated that the interaction between soft coral species, methods, and location significantly differed the average growth rates of the transplanted soft corals. The average survival rates demonstrated that there was no significant difference among transplanted soft coral species within similar locations in both methods. In contrast, the average survival rates of transplanted soft coral outside were significantly higher than those inside the bay in both methods that reached $>80 \%$.

2021 JMRT. All rights reserved.

\section{Pendahuluan}

Terumbu karang memiliki tingkat produktivitas dan keanekaragaman yang tinggi. Terumbu karang juga memiliki peranan penting dalam ekoesistem laut dengan berbagai macam fungsi yaitu fungsi ekologis dan fungsi ekonomi. Fungsi ekologi yaitu sebagai tempat mencari makan, tempat pemijahan dan pembesaran berbagai biota laut. Sementara, fungsi ekonomi ekosistem terumbu karang yaitu dapat sebagai sumber penghasilan masyarakat pesisir melalui perikanan karang, sebagai sumber karang hias untuk aquarium laut, dan sebagai objek wisata bahari (Direktorat Konservasi dan Keanekaragaman Hayati Laut, 2015).

Karang lunak yang termasuk dalam ordo Alcyonacea adalah penyusun utama kedua terbesar dari ekosistem terumbu karang. Karang lunak dapat ditemukan secara luas di perairan tropis dan berperan penting dalam ekologi terumbu global. Sebagian besar jenis karang lunak dapat ditemukan di landas kontinen, namun beberapa juga ditemukan pada laut dalam. Karang lunak terdapat dalam bentuk, ukuran dan warna yang bervariasi (Vinod et al., 2014) yang mendorong budidaya karang transplan yang bernilai ekonomi. Selain sebagai penyusun ekosistem terumbu karang, beberapa jenis karang lunak juga memiliki kandungan bioaktif yang dapat digunakan sebagai bahan baku obat-obatan seperti, anti-bakteri, anti-inflamasi, anti-tumor dan mengandung sitotoksik didalam jaringan tubuhnya (Vinod et al., 2014).

Transplantasi karang merupakan salah satu cara untuk menanam atau menumbuhkan koloni karang dengan cara fragmentasi buatan. Transplantasi ini biasanya dilakukan untuk rehabilitasi ekosistem karang yang rusak ataupun untuk kebutuhan akuarium (Soedharma dan Arafat, 2007 dalam Prastiwi, 2011). Umumnya metode transplantasi karang lunak dilakukan dengan cara menempelkan fragmen transplan karang pada substrat buatan dan diletakkan di atas meja transplan (Fitriani et al., 2020). Beberapa metode transplantasi karang yaitu antara lain metode patok kayu yang ditancapkan ke tanah, metode jaring, metode jaring dan substrat, metode jaring dan rangka, serta metode kombinasi jaring, rangka, dan substrat (Kurniawan, 201 dalam Direktorat Konservasi dan Keanekaragaman Hayati Laut, 2015). Beberapa metode ini memerlukan banyak komponen yang dinilai kurang praktis dan memerlukan biaya yang tidak sedikit. Oleh karena itu, perlu diketahui pertumbuhan dan kelangsungan 
hidup transplan karang lunak dengan metode transplantasi metode tebar dasar yaitu dengan cara meletakkan pada dasar perairan yang terdiri atas pecahan karang tanpa direkatkan atau ditempelkan pada substrat buatan yang juga diletakkan pada dasar perairan tanpa kerangka atau meja. Karang lunak Sinularia polydactyla dan S. asterolobata merupakan beberapa jenis karang lunak yang dibudidayakan oleh PT Dinar Darum Lestari di Teluk Pegametan, Kabupaten Buleleng, yang merupakan sebuah perusahaan eksportir biota laut hasil budidaya.

\section{Metode}

\subsection{Waktu dan Tempat}

Penelitian ini dilakukan pada Bulan Januari - April 2020 bertempat di Teluk Pegametan (807'11's 114'36'57'E), Perairan Desa Sumberkima, Kecamatan Gerokgak, Kabupaten Buleleng, Bali (Gambar 1).

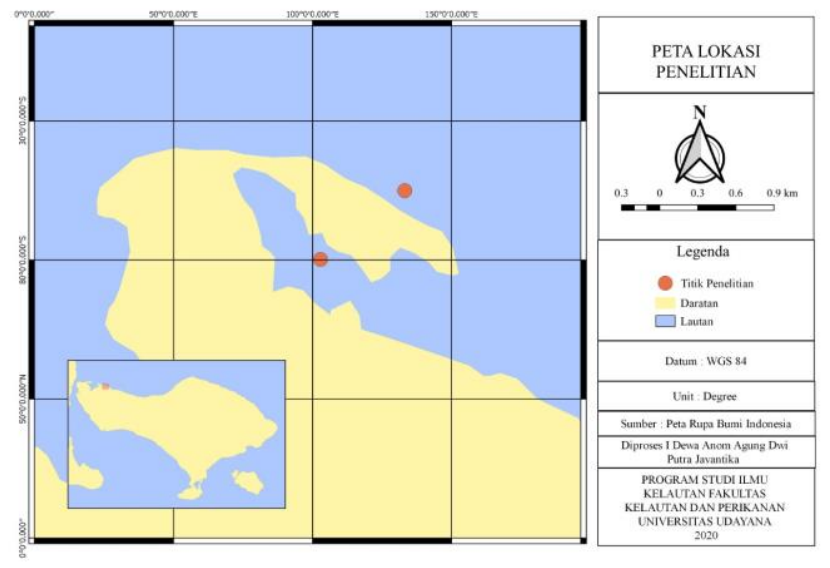

Gambar 1. Peta lokasi penelitian

\subsection{Prosedur Penelitian}

Penelitian ini dilakukan pada dua lokasi transplantasi yaitu di luar dan dalam teluk (Gambar 1) serta masing - masing lokasi terdapat dua metode transplantasi yaitu metode tebar dasar fragmen karang lunak dan penempelan fragmen karang lunak di substrat buatan. Karang lunak yang ditransplantasikan ada dua jenis yang berbeda yaitu $S$. polydactyla dan $S$. asterolobata. Masing-masing jenis karang lunak tersebut kemudian diukur laju pertumbuhan dan tingkat kelangsungan hidup setiap 2 minggu sekali selama 12 minggu. Parameter kualitas perairan yang diukur pada kedua lokasi adalah salinitas, $\mathrm{pH}$, kecepatan arus, suhu, kekeruhan dan kadar nutrien (nitrat dan fosfat). Prosedur kerja dari penelitian ini adalah sebagai berikut:

\subsubsection{Persiapan Jaring Pembatas}

Tahap pertama dalam melakukan penelitian ini adalah mempersiapkan 4 buah jaring pembatas dimana 2 buah diletakkan di dalam teluk dan 2 lainnya diletakkan di luar teluk dengan posisi yang bersebelahan. Jaring terbuat dari besi dipasang berbentuk persegi panjang dengan ukuran 1 x $2 \mathrm{~m}$ yang di dalamnya akan disekat kembali berukuran 30 x $30 \mathrm{~cm}$ (Gambar 2). Tujuan dipasangnya jaring pembatas adalah untuk melindungi karang lunak pada metode tebar dasar dan penempelan di substrat agar tidak terbawa arus dan memudahkan dalam melakukan pengukuran pertumbuhan.

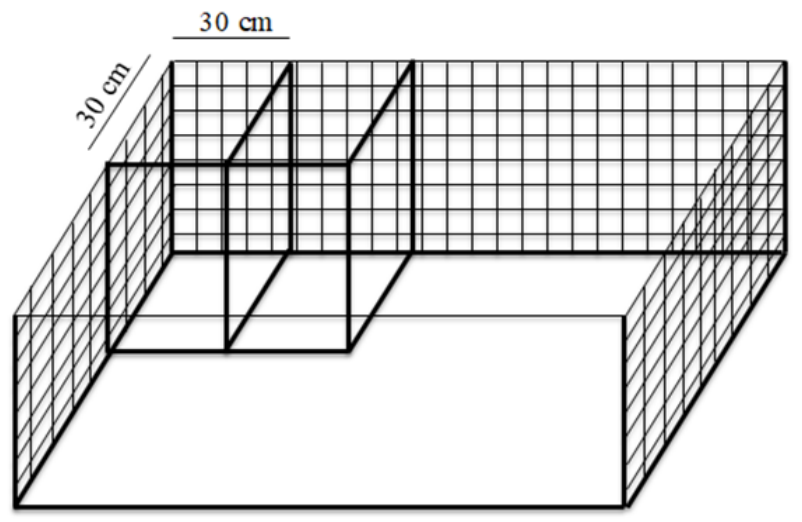

Gambar 2. Jaring pembatas transplan karang lunak

\subsubsection{Pengambilan Sampel Karang Lunak}

Sampel karang lunak didapatkan dari PT. Dinar Darum Lestari yang merupakan merupakan perusahaan yang bergerak di bidang kelautan dan perikanan yang salah satu divisinya yaitu ekspor transplan karang yang bertempat di desa Sumberkima, Kecamatan Gerokgak, Buleleng, Bali. Ukuran fragmen karang lunak yang akan digunakan adalah $\pm 5 \times 5 \mathrm{~cm}$. hal ini mengacu pada Edwards dan Gomez (2008) dimana semakin besar ukuran fragmen, maka memiliki tingkat kelulushidupan yang lebih tinggi.

\subsubsection{Metode Transplantasi}

Metode transplantasi yang digunakan ada dua yaitu metode tebar dasar dan penempelan di substrat buatan yang memiliki kedalaman 7 meter. Metode tebar dasar dilakukan dengan cara fragmen karang lunak ditebar pada substrat dasar yaitu rubble atau pecahan karang dimana prinsip metode ini mengacu pada penelitian Vinod et al., (2014) bahwa fragmen karang lunak hanya diletakkan pada dasar substrat tanpa direkatkan oleh apapun. Selanjutnya metode penempelan di substrat buatan dilakukan dengan cara memotong sampel karang lunak dengan ukuran yang sama selanjutnya direkatkan pada substrat campuran semen dan kerikil dengan cara dijahit dan diberi label sebagai penanda. Prinsip metode ini mengacu pada penelitian Prastiwi (2011), bahwa karang direkatkan pada substrat semen yang langsung diletakkan pada lokasi transplantasi tanpa meja. Terdapat masing-masing 5 fragmen karang lunak dengan jenis yang sama dan jarak antar spesies pada masing-masing metode adalah $30 \mathrm{~cm}$. Tata letak fragmen setiap jenis karang lunak pada kedua metode ditunjukkan pada Gambar 3.

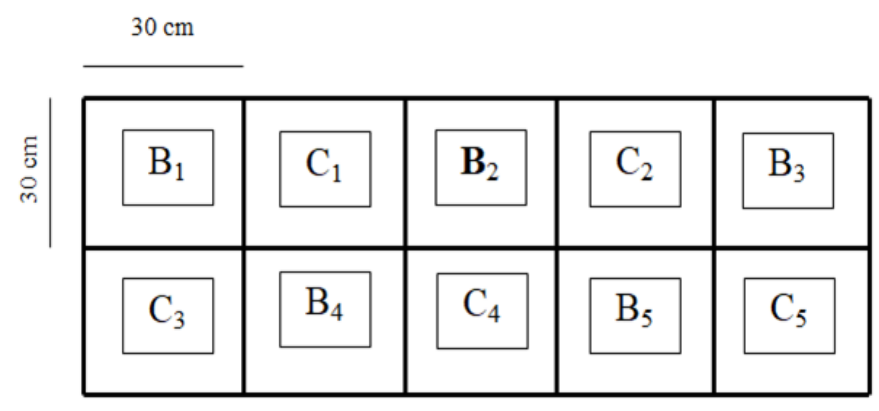

Gambar 3. Tata letak karang lunak transplan

Keterangan:

B = Karang lunak $S$. polydactyla 
C = Karang lunak S. asterolobata

1,2,3,4,5 = Ulangan ke-

\subsection{Analisa Data}

\subsubsection{Laju Pertumbuhan}

Data pertambahan luas fragmen karang lunak digunakan untuk menghitung laju pertumbuhan menggunakan rumus pada persamaan 1 (Ricker, 1975)

$\beta=(\mathrm{Lt}-\mathrm{L} 0) / \mathrm{t}$

Keterangan:

$\beta=$ Laju pertumbuhan fragmen karang lunak $\left(\mathrm{cm}^{2} / \mathrm{t}\right)$,

$\mathrm{Lt}=$ Rata-rata luas karang lunak pada akhir penelitian $\left(\mathrm{cm}^{2}\right)$,

L0 $=$ Rata-rata luas karang lunak pada awal penelitian $\left(\mathrm{cm}^{2}\right)$,

$\mathrm{t}=$ Waktu pengamatan karang lunak (minggu).

\subsubsection{Tingkat Kelangsungan Hidup}

Pengamatan tingkat kelangsungan hidup dilakukan untuk mengetahui tingkat keberhasilan transplantasi dilihat dari berapa persen karang lunak yang ditransplantasi tetap hidup dari awal hingga akhir penelitian. Tingkat kelangsungan hidup fragmen karang lunak dihitung berdasarkan persamaan 2 (Ricker, 1975).

$\mathrm{SR}=(\mathrm{Nt} / \mathrm{N} 0) \times 100 \%$

Keterangan:

SR = Tingkat kelangsungan hidup karang lunak (\%),

$\mathrm{Nt}=$ Jumlah fragmen karang lunak pada akhir penelitian,

N0 = Jumlah fragmen karang lunak pada awal penelitian.

\subsection{Analisa Statistik}

Perbedaan laju pertumbuhan karang lunak $S$. polydactyla dan $S$. asterolobata yang masing-masing ditransplantasikan pada lokasi dan metode yang berbeda dianalisa dengan uji ANOVA faktorial 3 faktor. Perbedaan tingkat kelangsungan hidup karang lunak $S$. polydactyla dan $S$. asterolobata yang masing-masing ditransplantasikan pada lokasi dan metode yang berbeda dianalisa dengan menggunakan uji Log Rank. Apabila terdapat perbedaan antar variabel tersebut $(\mathrm{P}<0,05)$, selanjutnya dilakukan uji Pairwise Comparisons untuk mengetahui adanya variabel yang menyebabkan perbedaan tersebut. Analisa statistik menggunakan aplikasi SPSS 21 .

\section{Hasil dan Pembahasan}

\subsection{Parameter Kualitas Lokasi Transplantasi}

Rata-rata nilai parameter kualitas perairan masing-masing lokasi transplantasi karang transplan ditunjukkan pada Tabel 1. Kisaran salinitas, suhu, $\mathrm{pH}$ dan kekeruhan di kedua lokasi relatif sama, kecuali suhu perairan di luar teluk pada minggu ke 8-10 yang lebih tinggi $2{ }^{0} \mathrm{C}$ daripada di dalam teluk. Kecerahan perairan di kedua lokasi relatif rendah yaitu $<50 \%$ di dalam teluk dan $<60 \%$ di luar teluk kecuali kecerahan di luar teluk pada minggu ke- 12 mencapai $80 \%$. Konsentrasi nutrien (nitrat dan posfat) cenderung sama di kedua lokasi budidaya sepanjang pengamatan kecuali pada minggu ke-2 dimana konsentrasi posfat di dalam teluk lebih tinggi daripada di luar teluk, sedangkan konsentrasi nitrat di luar teluk lebih tinggi daripada di dalam teluk.
Tabel 1. Rata-rata (mean \pm stdev) parameter kualitas perairan pada lokasi penelitian

\begin{tabular}{|c|c|c|c|c|c|c|c|c|}
\hline \multirow{2}{*}{ Parameter } & \multirow{2}{*}{ Lokasi } & \multicolumn{7}{|c|}{ Minggu ke- } \\
\hline & & 0 & 2 & 4 & 6 & 8 & 10 & 12 \\
\hline \multirow{2}{*}{$\begin{array}{c}\text { Salinitas } \\
\left(\%_{0}\right)\end{array}$} & $\mathrm{L}$ & $34 \pm 1,25$ & $33 \pm 0,82$ & $35 \pm 0,47$ & $35 \pm 1,25$ & $34 \pm 2,05$ & $34 \pm 0,82$ & $35 \pm 0,47$ \\
\hline & D & $35 \pm 0,82$ & $34 \pm 1,25$ & $34 \pm 0,47$ & $35 \pm 0,82$ & $35 \pm 0,94$ & $34 \pm 0,94$ & $34 \pm 0,47$ \\
\hline \multirow{2}{*}{$\mathrm{pH}$} & $\mathrm{L}$ & $7,53 \pm 0,27$ & $7,82 \pm 0,05$ & $7,68 \pm 0,81$ & $7,65 \pm 0,80$ & $7,13 \pm 0,12$ & $8,16 \pm 0,32$ & $8,14 \pm 0,38$ \\
\hline & D & $7,35 \pm 0,08$ & $7,54 \pm 0,37$ & $7,68 \pm 0,14$ & $7,22 \pm 0,06$ & $7,63 \pm 0,00$ & $8,15 \pm 0,20$ & $8,17 \pm 0,18$ \\
\hline Kecepatan & $\mathrm{L}$ & 0 & 0,153 & 0,057 & 0,059 & 0,344 & 0,357 & 0,37 \\
\hline Arus (m/s) & D & 0,019 & 0,027 & 0,016 & 0,005 & 0,097 & 0,005 & 0,008 \\
\hline \multirow{2}{*}{ Kecerahan } & $\mathrm{L}$ & $40 \pm 1,63$ & $45 \pm 2,45$ & $60 \pm 1,25$ & $65 \pm 2,45$ & $50 \pm 0,00$ & $60 \pm 2,05$ & $80 \pm 2,87$ \\
\hline & D & $25 \pm 0,47$ & $30 \pm 0,47$ & $40 \pm 2,05$ & $40 \pm 1,25$ & $25 \pm 0,47$ & $50 \pm 1,63$ & $20 \pm 0,00$ \\
\hline \multirow{2}{*}{ Suhu (C) } & $\mathrm{L}$ & $27 \pm 0,82$ & $28 \pm 0,00$ & $27 \pm 1,25$ & $27 \pm 0,47$ & $29 \pm 0,47$ & $29 \pm 0,47$ & $29 \pm 0,82$ \\
\hline & D & $27 \pm 0,47$ & $27 \pm 0,47$ & $28 \pm 0,82$ & $28 \pm 0,47$ & $27 \pm 1,25$ & $27 \pm 0,47$ & $27 \pm 0,82$ \\
\hline \multirow{2}{*}{$\begin{array}{c}\text { Kekeruhan } \\
\text { (NTU) }\end{array}$} & $\mathrm{L}$ & 1,83 & 1,75 & 1,84 & 2,40 & 2,63 & 2,91 & 2,37 \\
\hline & D & 2,08 & 1,97 & 1,93 & 2,60 & 2,77 & 3,02 & 2,99 \\
\hline Nitrat & $\mathrm{L}$ & - & 0,135 & 0,857 & 0,403 & 0,613 & 0,513 & 0,564 \\
\hline$(\mathrm{mg} / \mathrm{l})$ & D & - & 0,035 & 1,149 & 0,371 & 0,537 & 0,425 & 0,582 \\
\hline Posfat & $\mathrm{L}$ & - & 0,094 & $<0,01$ & $<0,01$ & $<0,01$ & $<0,01$ & $<0,01$ \\
\hline$(\mathrm{mg} / \mathrm{l})$ & $\mathrm{D}$ & - & 0,33 & $<0,01$ & 0,43 & $<0,01$ & $<0,01$ & $<0,01$ \\
\hline
\end{tabular}

Keterangan:

$\mathrm{L}=$ Luar teluk

$\mathrm{D}=$ Dalam teluk

\subsection{Tingkat Kelangsungan Hidup Karang Lunak}

\subsubsection{Metode Penempelan Substrat}

Grafik tingkat kelangsungan hidup transplan karang lunak pada metode penempelan substrat ditunjukkan pada Gambar 4 dimana terdapat empat kurva yang menunjukkan persentase tingkat kelangsungan hidup pada masing-masing jenis karang lunak, namun kurva antara spesies $S$. polydactyla (biru) dan $S$. asterolobata (merah) di luar teluk saling berhimpit sehingga kurva $S$. polydactyla (biru) tidak terlihat karena memiliki persentase yang sama. Hasil uji Log-rank menunjukkan bahwa rata-rata tingkat kelangsungan hidup antar jenis transplan karang lunak di lokasi transplantasi berbeda pada metode penempelan substrat buatan berbeda signifikan $(\mathrm{P}<0,05)$. Hasil Uji Pairwise Comparison mengindikasikan bahwa tingkat kelangsungan hidup jenis transplan karang lunak yang berbeda tetapi pada lokasi yang sama tidak berbeda signifikan yaitu $S$. polydactyla dan $S$. asterolobata yang ditransplantasi di dalam teluk $(\mathrm{P}=0,306)$ dan yaitu $S$. polydactyla dan $S$. asterolobata yang ditransplantasi di luar teluk $(\mathrm{P}=1,000)$. Transplan karang lunak $S$. polydactyla di dalam teluk hanya mampu bertahan hingga minggu ke-10 sedangkan kematian transplan karang lunak $S$. asterolobata di dalam teluk mulai terjadi pada minggu ke-8 dan hanya 3 transplan dapat bertahan hingga akhir penelitian (minggu ke-12). Rata-rata tingkat kelangsungan hidup transplan karang lunak yang ditransplantasi di luar teluk lebih tinggi daripada di dalam teluk yaitu $S$. polydactyla dan $S$. asterobalata yang ditransplantasikan di luar teluk mencapai $100 \%$ karena seluruh transplan dapat hidup sampai akhir penelitian (minggu 12). Rata-rata tingkat kelangsungan hidup transplan karang lunak $S$. polydactyla di luar teluk secara signifikan lebih tinggi dibandingkan di dalam teluk dimana seluruh transplan karang lunak yang berlokasi di dalam teluk tidak dapat bertahan hingga akhir penelitian $(\mathrm{P}=0,034)$. Tetapi, rata-rata tingkat kelangsungan hidup transplan karang lunak $S$. asterobalata tidak berbeda signifikan baik yang ditransplantasikan di dalam dan di luar teluk $(\mathrm{P}=0,198)$. 


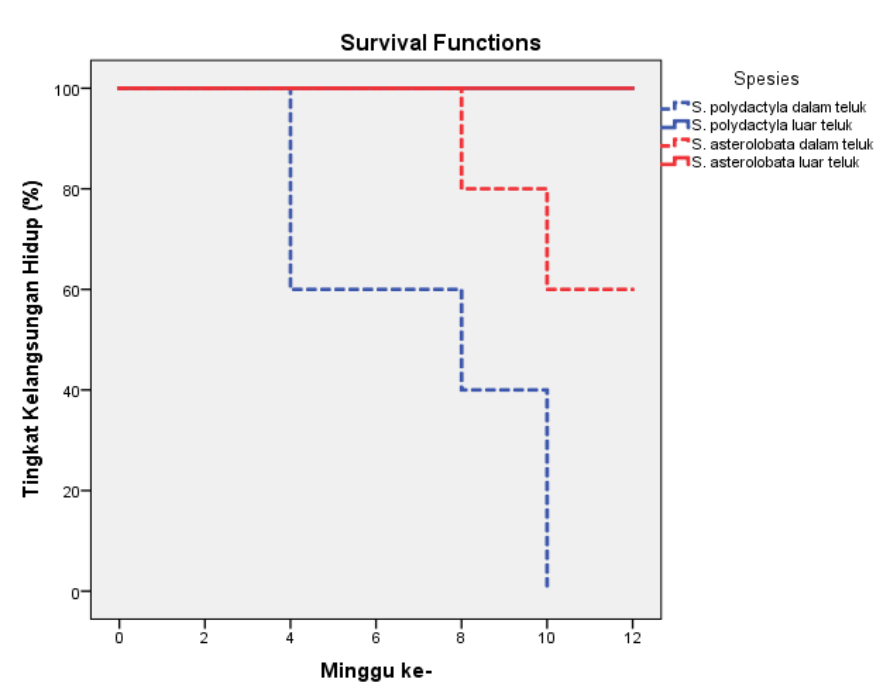

Gambar 4. Tingkat kelangsungan hidup pada metode penempelan substrat buatan pada lokasi dalam dan luar teluk.

\subsubsection{Metode Tebar Dasar}

Grafik tingkat kelangsungan hidup transplan karang lunak pada metode tebar dasar ditunjukkan pada Gambar 5. Hasil uji Log-Rank menunjukkan bahwa rata-rata tingkat kelangsungan hidup antar jenis transplan karang lunak dan lokasi transplantasi pada metode tebar dasar tidak berbeda signifikan $(\mathrm{P}>0,05)$. Ratarata tingkat kelangsungan hidup antar kedua jenis transplan karang lunak yang ditransplantasi di dalam teluk sama rendahnya yaitu $40 \%$. Kematian transplan karang lunak $S$. polydactyla pertama terjadi mulai minggu ke-2 dan hanya 2 transplan hidup sampai akhir penelitian sedangkan kematian transplan karang lunak $S$. asterolobata pertama terjadi mulai minggu ke-4 dan hanya 2 transplan hidup sampai akhr penelitian. Rata-rata tingkat kelangsungan hidup transplan karang lunak yang ditransplantasikankan di luar teluk lebih tinggi daripada di dalam teluk, dimana rata-rata tingkat kelangsungan hidup transplan karang lunak $S$. polydactyla yaitu $80 \%$ dengan hanya 1 transplan yang mati pada akhir penelitian karena tertutup oleh alga. Ratarata tingkat kelangsungan hidup transplan karang lunak $S$. asterolobata yang ditransplantasikan di luar teluk dapat mencapai $100 \%$.

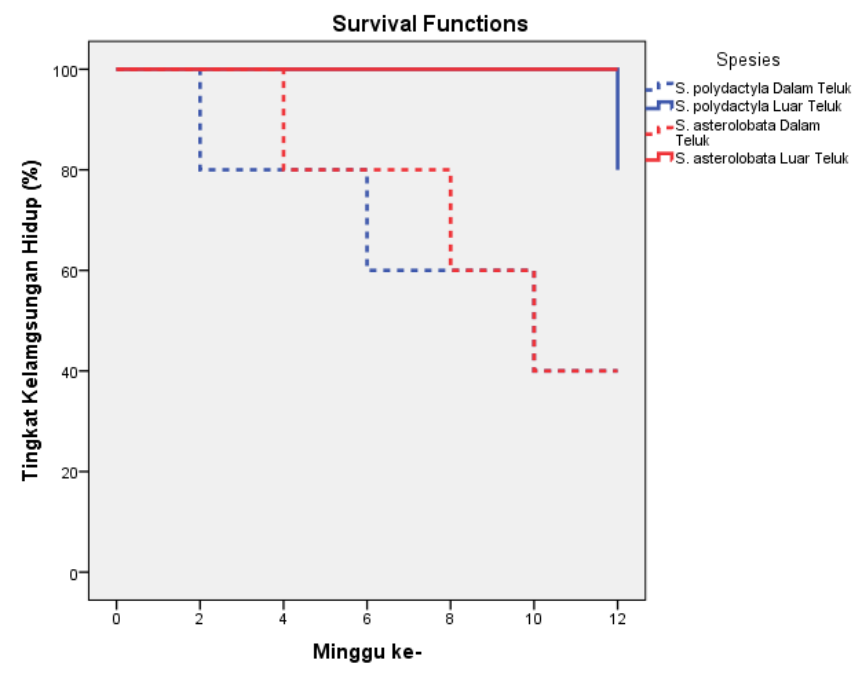

Gambar 5. Grafik tingkat kelangsungan hidup pada metode tebar dasar lokasi dalam dan luar teluk.
Tingginya tingkat kelangsungan hidup transplan karang lunak yang ditransplantasikan di luar teluk dipengaruhi oleh beberapa faktor. Faktor pertama adalah karang lunak yang ditransplantasikan harus memiliki kondisi oseanografis yang sama dengan asal indukan karang tersebut diambil, dimana pada penelitian ini indukan karang lunak diambil dari hasil budidaya yang berlokasi di luar teluk. Hal ini sejalan dengan pernyataan Rani (1999) dalam Hermanto (2015), bahwa untuk mendapatkan angka keberhasilan usaha transplantasi atau budidaya karang, perlu memperhatikan persamaan kondisi oseanografis antara daerah yang akan ditransplantasikan dengan daerah dimana karang itu berasal. Faktor kedua adalah adanya organisme kompetitor/predator antara lain seperti alga dan gastropoda yang terdapat pada lokasi transplantasi. Menurut Haris (2001), alga dapat mengganggu efektifitas pemanfaatan cahaya, kompetitor dalam mencari ruang dan bahkan dapat memotong jaringan tubuh karang lunak yang ditransplantasi, dimana pada penelitian ini alga menutupi beberapa jaringan karang transplan sehingga dapat menggangu proses fotosintesis.

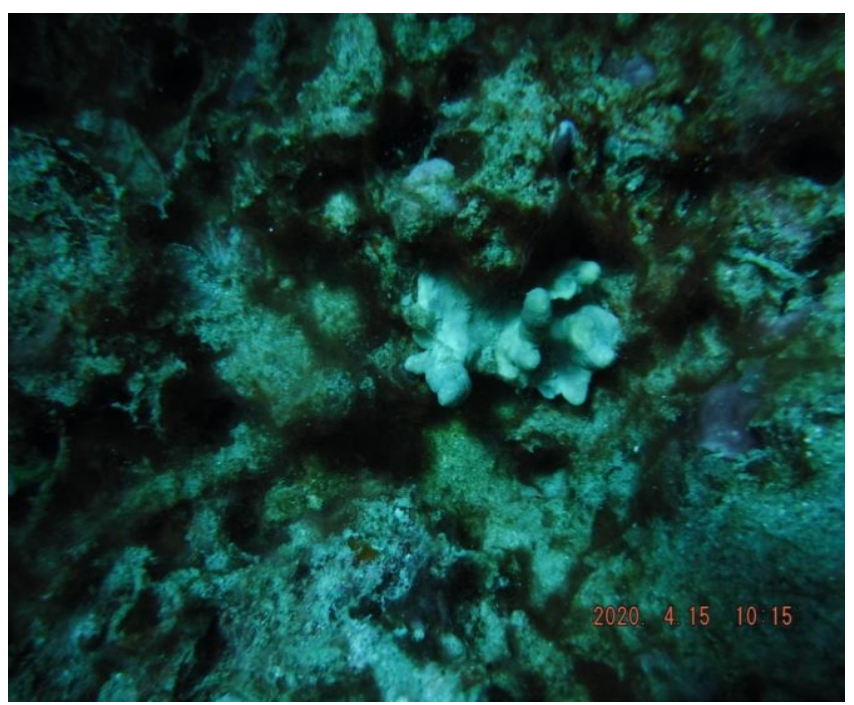

Gambar 6. Karang lunak yang mati karena ditutupi oleh alga.

Faktor selanjutnya adalah faktor sedimentasi, dimana sedimentasi yang tinggi diduga menghambat penempelan karang lunak pada substrat (metode tebar dasar) dan dapat menghalangi penetrasi cahaya matahari yang digunakan pada fotosintesis alga simbion di karang lunak (DeMartini et al., 2013). Sedimentasi ditunjukkan dengan nilai kekeruhan yang tinggi di dalam teluk total yaitu 2,48 NTU dan tingkat kecerahan $<50 \%$. Larcombe et al. (1995) menyatakan bahwa walaupun tidak ada nilai tertentu yang dijadikan acuan seberapa besar nilai turbiditas untuk terumbu karang dapat hidup dan sehat, nilai turbiditas $<1$ merupakan nilai turbiditas yang normal, namun menurut baku mutu air laut, tingkat kekeruhan di dalam teluk masih di bawah baku mutu ( $<5$ NTU). Nutrien juga dapat mempengaruhi kelangsungan hidup karang dimana besarnya kadar nutrien dapat memicu tumbuh makroalga dengan pesat yang dapat menyebabkan kecerahan menurun (Djaelani, 2011). Hasil penelitian ini serupa dengan penelitian oleh Nugroho (2008) pada spesies Sinularia dura dimana persentase tingkat kelangsungan hidupnya mencapai $100 \%$. Hal ini diduga karena indukan karang transplan diambil tidak jauh dari lokasi transplantasi, sehingga dapat mempermudah proses adaptasi karang transplan. Hasil penelitian oleh Mohammed (2003) pada jenis karang keras dan karang lunak menunjukkan persentase total $84,2 \%$ dimana $16 \%$ kematian pada karang transplannya diakibatkan oleh alga, spons, 
dan moluska. Laju sedimantesi juga berperan dalam kematian karang transplan karena karang ditemukan terkubur oleh sedimen.

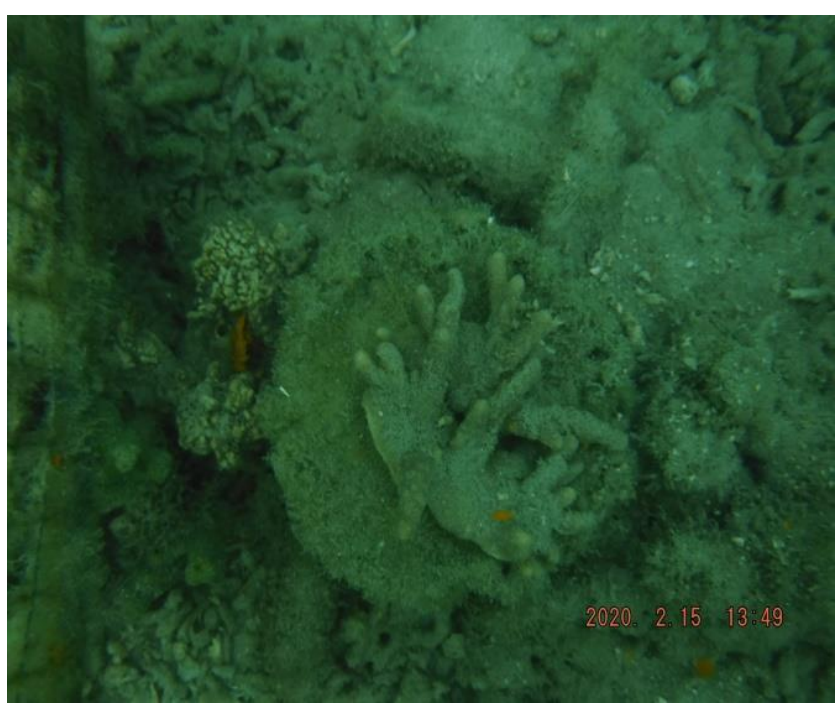

Gambar 7. Karang lunak yang ditutupi sedimentasi.

\subsection{Rata-rata laju pertumbuhan transplan karang lunak yang ditransplantasi pada metode dan lokasi berbeda}

Rata-rata laju pertumbuhan karang lunak yang ditransplantasi dengan metode tebar dasar dan penempelan substrat di luar dan dalam Teluk Pegametan ditunjukkan pada Tabel 2. Rata-rata laju pertumbuhan karang lunak yang ditransplantasikan di luar teluk memiliki nilai yang lebih tinggi dibandingkan di dalam teluk. Hasil uji ANOVA tiga arah menunjukkan bahwa tidak terdapat perbedaan laju pertumbuhan antar jenis transplan karang lunak $(\mathrm{P}$ $=0,104)$ dan tidak terdapat perbedaan laju pertumbuhan transplan karang lunak pada metode berbeda $(P=0,141)$, tetapi rata-rata laju pertumbuhan transplan karang lunak berbeda signifikan antar lokasi budidaya $(P=0,025)$. Selain itu, hasil uji ANOVA tiga arah juga mengindikasikan bahwa perbedaan rata-rata laju pertumbuhan transplan karang lunak bukan merupakan hasil interaksi antara jenis transplan karang lunak dan metode $(\mathrm{P}=$ $0,321)$, jenis transplan karang lunak dan lokasi budidaya $(\mathrm{P}=$ $0,586)$ atau metode dan lokasi budidaya $(\mathrm{P}=0,890)$, melainkan merupakan hasil interaksi antara ketiga variabel tersebut bersamasama $(P=0,007)$.

Tidak terdapat perbedaan laju pertumbuhan antar kedua jenis karang lunak diduga karena kedua transplan karang lunak merupakan anggota genus Sinularia yang memiliki polip bersifat monomorfik atau seragam (Fabricius dan Alderslade 2001), sehingga kedua jenis karang lunak dapat memiliki kemampuan mencari makan dan beradaptasi terhadap lingkungan yang sama. Selain itu, kedua lokasi transplantasi memiliki nilai parameter lingkungan yang relatif sama, kecuali kecepatan arus dimana pada lokasi luar teluk memiliki kecepatan arus yang optimal untuk karang hidup. Rata-rata laju pertumbuhan antar jenis transplan karang lunak pada kedua metode juga tidak memiliki perbedaan signifikan. Hal ini diduga karena dilakukan perlakuan yang sama terhadap kedua metode transplantasi seperti pembersihan alga yang menempel dan pengambilan organisme predator (gastropoda) setiap 2 minggu. Walaupun secara statistik, tidak terdapat perbedaan signifikan pada rata-rata laju pertumbuhan, namun rata-rata laju pertumbuhan transplan karang lunak dengan metode penempelan di substrat buatan lebih tinggi dibandingkan metode tebar dasar. Hal ini diasumsikan karena waktu yang dibutuhkan oleh transplan karang lunak untuk mendapatkan substrat untuk menempel lebih cepat dibandingkan dengan metode tebar dasar. Dengan demikian substrat memiliki pengaruh penting terhadap laju pertumbuhan karang, hal ini sesuai dengan pernyataan Thamrin (2006) bahwa salah satu faktor yang mempengaruhi keberhasilan fragmentasi karang adalah tipe substrat tempat fragmen diletakkan. Hasil pada penelitian ini serupa dengan penelitian sebelumnya yang dilakukan oleh Fitriani (2020) dimana laju pertumbuhan transplan karang lunak Cladiella $s p$. dengan metode penempelan di substrat semen dan rubble di akuarium didapatkan bahwa tidak ada perbedaan laju pertumbuhan transplan karang lunak pada kedua metode.

Tabel 2. Rata-rata (mean \pm stdev) laju pertumbuhan transplan karang lunak yang ditransplantasikan pada metode dan lokasi berbeda

\begin{tabular}{|c|c|c|c|c|c|}
\hline Metode & Lokasi & $\begin{array}{l}\text { Jenis karang } \\
\text { lunak }\end{array}$ & $\begin{array}{c}\text { Ukuran } \\
\text { Awal } \\
\left(\mathrm{cm}^{2}\right)\end{array}$ & $\begin{array}{c}\text { Ukuran } \\
\text { Akhir } \\
\left(\mathrm{cm}^{2}\right)\end{array}$ & $\begin{array}{c}\text { Laju } \\
\text { Pertumb } \\
\text { uhan } \\
\left(\mathrm{cm}^{2} / 2\right. \\
\text { minggu })\end{array}$ \\
\hline \multirow{4}{*}{$\begin{array}{l}\text { Penempelan } \\
\text { di Substrat }\end{array}$} & \multirow{2}{*}{$\begin{array}{l}\text { Dalam } \\
\text { Teluk }\end{array}$} & S. polydactyla & $\begin{array}{c}35,56 \pm \\
2,25\end{array}$ & $\begin{array}{c}50,5 \pm \\
9,02\end{array}$ & $\begin{array}{c}2,13 \pm \\
1,41\end{array}$ \\
\hline & & S. asterolobata & $\begin{array}{c}37,72 \pm \\
2,62\end{array}$ & $\begin{array}{c}82,78 \pm \\
13,95\end{array}$ & $\begin{array}{c}6,44 \pm \\
2,82\end{array}$ \\
\hline & \multirow{2}{*}{$\begin{array}{l}\text { Luar } \\
\text { Teluk }\end{array}$} & S. polydactyla & $\begin{array}{c}37,81 \pm \\
3,62\end{array}$ & $\begin{array}{c}79,83 \pm \\
17,43\end{array}$ & $\begin{array}{c}6,00 \pm \\
2,36\end{array}$ \\
\hline & & S. asterolobata & $\begin{array}{c}35,28 \pm \\
3,65\end{array}$ & $\begin{array}{c}79,89 \pm \\
14,81\end{array}$ & $\begin{array}{c}6,37 \pm \\
2,35\end{array}$ \\
\hline \multirow{4}{*}{ Tebar Dasar } & & S. polydactyla & $\begin{array}{c}35,42 \pm \\
1,22\end{array}$ & $\begin{array}{c}66,65 \pm \\
3,15\end{array}$ & $\begin{array}{c}4,46 \pm \\
0,35\end{array}$ \\
\hline & $\begin{array}{l}\text { Dalam } \\
\text { Teluk }\end{array}$ & S. asterolobata & $\begin{array}{c}38,70 \pm \\
1,32\end{array}$ & $\begin{array}{c}54,78 \pm \\
8,42\end{array}$ & $\begin{array}{c}2,30 \pm \\
0,76\end{array}$ \\
\hline & \multirow{2}{*}{$\begin{array}{l}\text { Luar } \\
\text { Teluk }\end{array}$} & S. polydactyla & $\begin{array}{c}37,08 \pm \\
2,77\end{array}$ & $\begin{array}{c}64,63 \pm \\
9,84\end{array}$ & $\begin{array}{c}3,94 \pm \\
1,89\end{array}$ \\
\hline & & S. asterolobata & $\begin{array}{c}37,94 \pm \\
5,92\end{array}$ & $\begin{array}{c}83,72 \pm \\
8,00\end{array}$ & $\begin{array}{c}6,54 \pm \\
1,34\end{array}$ \\
\hline
\end{tabular}

Rata-rata laju pertumbuhan transplan karang lunak yang ditransplantasi di luar teluk secara signifikan lebih tinggi daripada di dalam teluk. Hal ini diduga disebabkan oleh kecepatan arus dimana di luar teluk masuk kedalam kategori yang optimal untuk pertumbuhan karang lunak yaitu $0,1-<3 \mathrm{~m} / \mathrm{s}$, sedangkan di dalam teluk masuk kedalam kategori tidak ideal untuk transplantasi karang karena memiliki kecepatan arus sebesar $<0,1 \mathrm{~m} / \mathrm{s}$ (Sahetapy, 2016). Kecepatan arus yang optimal sangat diperlukan oleh terumbu karang sebagai media yang membawa nutrien dan oksigen serta mencegah terjadinya sedimentasi yang tidak baik untuk pertumbuhan karang (Pangaribuan, 2013). Selain itu, adanya organisme kompetitor (alga) dan predator (gastropoda) diduga berperan dalam menurunkan laju pertumbuhan yang keberadannya lebih dominan didalam teluk dibandingkan luar teluk. Keberadaan gastropoda tersebut terlihat pada bekas luka pada transplan karang lunak. Kekeruhan yang tinggi di dalam teluk yang juga terindikasi dari nilai kecerahan $<50 \%$ dapat menyebkan rendahnya rata-rata laju pertumbuhan transplan karang lunak di dalam teluk. Nutrien juga menjadi faktor tingginya kekeruhan yang dapat menyebabkan kurangnya intensitas cahaya sehingga dapat menghambat terjadinya fotosintesis alga simbion (Zooxanthellae) (Thamrin, 2004). 


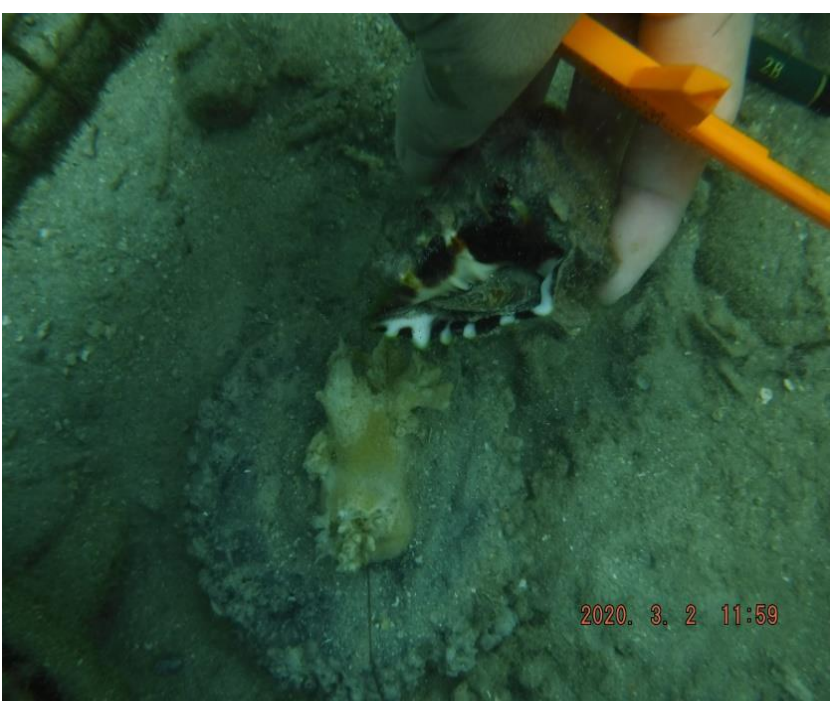

Gambar 8. Organisme predator (Gastropoda) yang berada di sekitar karang lunak

\section{Kesimpulan}

Rata-rata laju pertumbuhan transplan karang lunak antara spesies $S$. polydactyla, dan $S$. asterolobata yang ditransplantasikan dengan metode tebar dasar dan penempelan di substrat buatan pada kedua lokasi tidak berbeda signifikan. Ratarata laju pertumbuhan transplan karang lunak yang ditransplantasikan di luar teluk secara signifikan lebih tinggi yaitu $5,71 \mathrm{~cm}^{2}$ daripada di dalam teluk yaitu $3,83 \mathrm{~cm}^{2}$. Rata-rata laju pertumbuhan transplan karang lunak yang ditransplantasikan dengan metode penempelan substrat buatan dan tebar dasar tidak menunjukkan perbedaan yang signifikan. Interaksi antara jenis transplan karang lunak, metode transplantasi dan lokasi transplantasi bersama-sama memberikan perbedaan rata-rata laju pertumbuhan transplan karang lunak. Rata-rata tingkat kelangsungan hidup jenis transplan karang lunak yang berbeda tetapi pada lokasi yang sama tidak berbeda signifikan pada kedua metode. Rata-rata tingkat kelangsungan hidup transplan karang lunak di luar teluk secara signifikan lebih tinggi daripada di dalam teluk, dimana rata-rata tingkat kelangsungan hidup kedua transplan karang lunak mencapai lebih dari $80 \%$ pada kedua metode.

\section{Ucapan Terima Kasih}

Penulis mengucapkan terimakasih kepada Laboratorium Ilmu Kelautan, Fakultas Kelautan dan Perikanan Universitas Udayana dan PT. Dinar Darum Lestari yang telah memfasilitasi pelaksanaan penelitian ini.

\section{Daftar Pustaka}

[Dit KKHL] Direktorat Konservasi dan Keanekaragaman Hayati Laut. 2015. Pedoman Rehabilitasi Terumbu Karang (Scleractinia). Kementrian Kelautan dan Perikanan. $88 \mathrm{hlm}$.

[MENKLH] Menteri Negara Lingkungan Hidup. 2008. Keputusan Menteri Negara Lingkungan Hidup No. 51 Tahun 2004 Tentang Baku Mutu Air Laut. Jakarta
DeMartini E, Jokiel P, Beets J, Stender Y, Storlazzi C, Minton D, dan Conklin E. 2013. Terrigenous Sediment Impact on Coral Recruitment and Growth Affects the Use of Coral Habitat by Recruit Parrotfishes (F. Scaridae). Journal of Coastal Conservation, 17:417-429.

Djaelani A, Damar A, Rahardjo S. 2011. Kajian Kondisi Terumbu Karang dan Kaitannya dengan Proses Eutrofikasi di Kepulauan Seribu. Jurnal Ilmuilmu Perairan dan Perikanan Indonesia Jilid 17. Nomor 1: 187-194.

Edwards, A J, Gomez, E D.2008. Konsep dan Panduan Restorasi Terumbu: Membuat Pilihan Bijak di antara Ketidakpastian. Terj. dari Reef Restoration Concepts and Guidelines: Making Sensible Management Choices in The Face Of Uncertainly. University Of Queensland,iv + 38 $\mathrm{HIm}$

Fabricius K E, Alderslade P. 2001. Soft corals and sea fans: a comprehensive guide to the tropical shallow water genera of the central-west Pacific, the Indian Ocean and the Red Sea. Australian Institute of Marine Science: Townsville. ISBN 0-642-32210-4. VIII, 264 pp

Fitriani D P, Zainuri M, Nugraha W A. 2020. Laju Pertumbuhan dan Pertumbuhan Mutlak Karang Lunak Cladiella sp. pada Substrat yang Berbeda. Jurnal Kelautan Tropis Vol. 23(1):29-38. Universitas Trunojoyo Madura

Haris A. 2001. Laju Pertumbuhan dan Tingkat Kelangsungan Hidup Fragmentasi Buatan karang Lunak (Octocorallia: Alcyonacea) Sarchophyton trocheliophorum Von Marenzeller dan Lobophytum strictum TixierDurivault di Perairan Pulau Pari, Kepulauan Seribu [Thesis]. Bogor: Institut Pertanian Bogor. $105 \mathrm{Hlm}$.

Hermanto B. 2015. Pertumbuhan Fragmen Acropora formosa pada Ukuran yang Berbeda dengan Metode Transplantasi di Perairan Selat Lembeh. UPT. Loka Konservasi Biota Laut LIP. Bitung. Sulawesi Utara.

Larcombe P, Ridd, P V, Prytz A dan Wilson B. 1995. Factors controlling suspended sediment on innershelf coral reefs, Townsville, Australia. Coral Reefs 14: 163-171

Mohammed M A K. 2003. Transplantation of Corals as an Approach to Rehabilitate The Degraded Reefs in The Egyptian Red Sea. Marine Science Department, Faculty of Science, Suez Canal University, Ismailia, Egypt. yptian Journal of Biology.

Nugroho S C.2008. Tingkat Kelangsungan Hidup dan Laju Pertumbuhan Transplantasi Karang Lunak Sinularia dura dan Lobophytum strictum di Pulau Pramuka, Kepulauan Seribu, Jakarta. [Skripsi]. Program Studi Ilmu Dan Teknologi Kelautan Fakultas Perikanan Dan Ilmu Kelautan Institut Pertanian Bogor. $76 \mathrm{Hlm}$.

Pangaribuan, T. H. Sordarsono, P. Dan Churun, A. 2013. Hubungan Kandungan Nitrat dan Fosfat Dengan Densitas Zooxanthellae Pada Polip Karang Acropora Sp. di Perairan Terumbu Karang Pulau Menjangan Kecil, Karimun Jawa. Semarang: Universitas Diponegoro. Diponegoro Journal Of Maquares Volume 2, Nomor 4. Hlm 136-145

Prastiwi D A. 2011. Pertumbuhan Karang Lunak Lobophytum Strictum Hasil Transplantasi Pada Sistem Resirkulasi Dengan Kondisi Cahaya Berbeda [Skripsi]. Departemen Ilmu Dan Teknologi Kelautan. Fakultas Perikanan Dan Ilmu Kelautan Institut Pertanian Bogor. $68 \mathrm{Hlm}$.

Ricker, W E. 1975. Computation and interpretation of biological statistics of fish populations. Bulletin 191. Department of The Environment Fisheries and Marine Service, Ottawa, Canada

Sahetapy, D. 2016. Penzonasian dan Penatakelolaan Kawasan Konservasi Perairan Teluk Tuhaha Berbasis Ekosistem. Proposal Disertasi. Program Doktor (S3), Program Studi Ilmu Kelautan, Pascasarjana Universitas Pattimura. Ambon. Hal: 88-92

Soedharma D, Arafat D. 2007. Perkembangan Transplantasi Karang di Indonesia. Prosiding Seminar Transplantasi. Bogor, 8 September 2005. Pusat Penelitian Lingkungan Hidup-Lembaga Penelitian dan Pengabdian Masyarakat. IPB.

Thamrin, Hafiz M, Mulyadi A. 2004. Pengaruh Kekeruhan Terhadap Densitas Zooxanthellae Karang Scleractinia Acropora aspera di Perairan Pulau Mursala dan Pulau Poncan Sibolga, Sumatera Utara. Jurnal Ilmu Kelautan Vol. 9 (2):82-85. ISSN 0853 - 7291.

Thamrin, 2006. Karang: Biologi Reproduksi \& Ekologi. Minamandiri Press. Pekanbaru.

Vinod K et al. 2014. Artificial Propagation of Soft Coral Sinularia kavarattiensis (Octocorallia: Alcyonacea) in India. Research Centre of ICAR-Central Marine Fisheries Research Institute No.222 : 3-6 